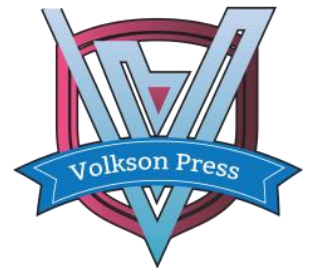

Contents List available at VOLKSON PRESS

Economics \& Management Innovations(EMI)

DOI : http://doi.org/10.26480/icemi.01.2017.417.418

\title{
Research on the EndingLogistics Distribution Mode in Higher Education Institutions
}

\author{
Li LI' ${ }^{1}$, Ai Zhu' ${ }^{1 *}$ and Qiuju Xu${ }^{1}$
}

${ }^{1}$ School of Management, Wuhan DonghuCollege, Wuhan, China *Email: 842209447@qq.com

This is an open access article distributed under the Creative Commons Attribution License, which permits unrestricted use, distribution, and reproduction in any medium, provided the original work is properly cited.

\section{ARTICLE DETAILS}

\section{Article History:}

Received 02 october 2017 Accepted 06 october 2017 Available online 11 october 2017

Keywords:

higher education institutions, logistics distribution mode.

\section{ABSTRACT}

This paper researches the service quality of ending logistics Distribution Modes in campus. To visit and investigation of several universities in Wuhan. To classifies the campus logistics models. To find out the problems existing in some aspects such as distribution scope, distribution time and quality of logistics distribution in higher education institutions, and put forward corresponding measures to improve the ending logistics distribution modes.

\section{Introduction}

Recent years has witnessed gradual maturity of the electronic commerce industry, the popularization of online shopping platform and the consumption improvement of university, all of which provides the huge market and the business opportunity for the logistics company in the university campus . According to the latest statistical analysis of Alipay in 2016 , more than $55 \%$ of college students across the country have joined the online shopping force, with an average annual spending of more than 4000 yuan on the Internet. As more and more students join the ranks of online shopping, campus logistics is being challenged, and exposed a lot of problems.

\section{The ending logistics distribution mode in higher education institutions}

This paper chooses 3 universities in Wuhan suburb as the research object, Wuhan Donghu College, Hankou College, Wuhan College, respectively. All of which is located 8-15 km from the city center with the total number of university teachers and students up to10000,and 30,000 pieces of express will be dealt with on average every month in the campus. There are several Logistics Distribution modes:

\subsection{Fixed agent station mode}

Since the number of teachers and students in the campus is quite concentrated, the volume of the express companies and electric companies with great handing volume will prefer to set up a fixed agent station in the university, which could be generally embodied in the followings: the first mode is proprietary agent point with the leasing fixed storefront of university logistics group as agent station, such as SF Express, ZTO Express and STO Express as well as other express company . the second model is to cooperate with the stores in the university, where shop owner could serves as agent. Dangdang is just the specific example. The advantage of this model is that it can greatly reduce the cost. The third model is to establish the school express service center, such as postal and EMS. No matter in which mode, its service could be demonstrated by sending text messages or telephone to inform teachers and students to get their deliveries in the express service station.

The advantages for fixed agent station mode are listed as follows: 1 , the time to get the delivery is more free. When receiving the message, its' appropriate to get the targeted delivery within two or three days, and if not, the agent will keep it for several days. 2, the space for fixed agent station is not small, and the deliveries have been placed so that consumers can quickly find their own goods.

\subsection{Mobile service spot (electric-business-led) mode}

Some electric business enterprises have no fixed agency station in campus, for they prefer the mobile station mode. Such a model is a logistics model with the electric business company as the leader, such as Jingdong, Vipshop and JUMEI. All of which prefer that couriers could drive to the school gate at a fixed time every day so that teachers and students will come and get their deliveries. The advantage of such a model is that first of all, it will save costs. As for electric business enterprises, university teachers and students all live in a quite concentrated place, so there is no need to rely on courier companies to deliver the goods, and rent campus shops. In this regard, rent could be saved. Secondly, as for the electrical business enterprises, they can take a good control of the time to send and receive couriers with relatively convenient management.

3. The problems existing in ending logistics distribution mode in higher education institutions

\subsection{Some problem existing in fixed agent station mode}

(1) The location for fixed agent station is unreasonable, which could be manifested in the following aspects: Firstly, each station is far from each other, and if there are some deliveries need to getting from different express companies, teachers and students need to go back and forth, which will take some time. Taking Wuhan Donghu College as an example, among its 6 fixed stations, there are only 2 of them in the dormitory area, in which it's far from other service stations. The average distance among 6 service stations is $1500 \mathrm{M}$ with 10 minutes average walking time, so the delivery is quite inconvenient and there exists quite great space for optimization. (2) Management is not so standard. 50\% fixed agent station has cooperated with shops, while is not conducive to the management and safety of goods; when there are so many various kinds of people coming and going. (3) Insufficient service capacity. During the time when the amount of deliveries is rocketing, such as "Double 11" or "6.18" festival, the express packages have often been scattered and troublesome to be found. (4) The problems concerning cooperating with the university. such as postal and EMS, Because there is no professional staff ,the staff are mostly school logistics staff or student volunteers who give help in turn. All of them have never received professional training without any working experience in respect of courier classification, sorting and 
arrangement. So,there always exist some situations that express packages have been damaged and lost.

\subsection{The problem of mobile service spot (electric quotient- dominated)}

(1) The safety of commodities. As there is no fixed express spot, courier packages are often directly transported by small trucks to the school gate. When teachers and students come to collect their goods, the packages have been randomly placed in the trunk, disorderly, in which there exists the security hidden trouble that the package may be mistakenly take away. At the same time owing to the small storage space, the goods may be easily damaged. (2) Pickup time is too short, easy to conflict with the consumer personal time, resulting in secondary distribution. (3) The express vehicles which randomly park at campus door, and the express packages which have been placed on the ground, all have exerted a serious effect on the campus appearance and traffic order. (4) This model is affected by weather conditions, such as rainy days, it's not so convenient to pick up.

\subsection{Lack of service awareness and service level}

(1) It fails to provide home delivery service. In order to save the cost, the participation of home delivery service is far from satisfaction during the ending logistic distribution in higher education institutions.

(2) The service staff is unstable along with poor service quality. Staff members are often replaced and have not received professional training .

(3) Consumers lack the initiative for the time and place they will get their delivery. According to the survey on the home delivery service and self-delivery in three universities in Wuhan suburb, the number of consumers will purchase goods via express 8.5 times. Among them, 1.4 times could enjoy the home delivery service, while 8.6 times they need to go to the express spot for getting their goods, in which 3.2 times, Consumers need to go to the designated location to receive courier in a specific period of time, which gives consumers a lot of inconvenience.

Table 1 Classification questionnaire on the way that deliveries will be taken in some higher education institutions in Wuhan

\begin{tabular}{l|l|l|l}
\hline & $\begin{array}{l}\text { Home } \\
\text { delivery } \\
\text { service }\end{array}$ & $\begin{array}{l}\text { Self-delivering at any } \\
\text { time } \\
\text { (fixed express spot) }\end{array}$ & $\begin{array}{l}\text { Self-delivering } \\
\text { with limited } \\
\text { time(mobile } \\
\text { express spot) }\end{array}$ \\
\hline $\begin{array}{l}\text { Number of services } \\
\begin{array}{l}\text { Per capita } \\
\text { acceptance by } \\
\text { consumers } \\
\text { (times/month) }\end{array}\end{array}$ & 1.4 & 3.6 & 3.3 \\
\hline Type of commodity & $\begin{array}{l}\text { Cake, } \\
\text { flowers }\end{array}$ & $\begin{array}{l}\text { Daily necessities, } \\
\text { school supplies, } \\
\text { clothing, food, etc. }\end{array}$ & $\begin{array}{l}\text { Electronic } \\
\text { products, } \\
\text { cosmetics, } \\
\text { clothing, etc. }\end{array}$ \\
\hline Service providers & $\begin{array}{l}\text { Cake } \\
\text { shop, } \\
\text { flowers }\end{array}$ & $\begin{array}{l}\text { express companies, } \\
\text { such as STO Express, } \\
\text { ZTO Express, ,SF } \\
\text { Express, EMS, } \\
\text { Dangdang, } \\
\text { Amazon,etc. }\end{array}$ & $\begin{array}{l}\text { Jipshop, JUMEI, } \\
\text { etc. }\end{array}$ \\
\hline
\end{tabular}

\section{Measures for improving the ending logistic mode in campus}

\subsection{Reasonable location, optimize the layout}

(1) The location for fixed logistics service spot should be considered from the perspective of servicing teachers and students, for example, the dormitory and canteen area.

(2) Each logistics company should communicate with each other in the site selection.,neither too concentrated, and not too scattered;

(3) It's advisable that each logistics company should also fully communicate with the school so as to achieve a reasonable layout and standardized management on the basis of servicing for overall norms in campus, all of which should not only safeguard the campus' appearance, but also facilitate the teachers and students to get their deliveries.

\subsection{Standardizing the management of mobile service stations}

(1) Fixed pick-up location. Mobile service station and trucks have casually placed, which not only affects the campus appearance, but also brings inconvenience for teachers and students to find. It's advisable that the electrical business enterprises with mobile service stations should actively consult with the school so as to strive for a fixed and spacious parking lot so that it's convenient for teachers and students to take their deliveries.

(2) To extend the time to take delivery and reduce the costs brought by customer who take goods for second time.

(3) To further strengthen the cooperation and integration among the express industry, and mobile service station can gradually replace the mobile service spot when cooperating with the fixed service spot.

\subsection{Optimizing the service and gradually realizing the home delivery service}

At present, the participation of home delivery service is insufficient in campus ending logistics. However, according to the survey, more than $70 \%$ of teachers and students prefer home delivery service, and $60 \%$ of them are willing to accept the premise of charging fees for such a service. Therefore, the profit margin for home delivery service in the campus is relatively large. The express company and the electric business enterprise should improve this businesses. For example, why not find some part-time couriers who can get paid in accordance the goods they have delivered? By doing so, it not only can reduce the operating costs and improve the service level, but also offer a more perfect service for consumers.

\subsection{Integration of express resources and reconstruction of express service ending system}

At present, there's a vicious competition among the various express companies in the campus, with business management out of order. For example, some colleges and universities set up a campus logistics center, the school logistics group coordinate and regulate the logistics service points, student associations, courier companies pay, it can reduce logistics costs. In some colleges, logistics companies has constructed the fixed selfmade cabinet in the campus so that the teacher and students can get their deliveries at any time within 24 hours, thus greatly bringing great convenience to the teachers and students.

\section{Acknowledgement}

This work was supported by the grants from Hubei Provincial Collaborative Innovation Centre of Agricultural E-Commerce (under Construction ) (Wuhan Donghu university research [2016] No. 15 Document).

\section{References}

[1] Mengke Yang, Xiaoguang Zhou. Construction of cooperative distribution mode of express terminal under the background of "Internet +". [J]. Journal of Beijing Telecommunications University, 2015, (12).

[2] Yanran Huang, GuangxianWu. Study on the receiving mode of the last kilometer distribution of electronic commerce[J].Journal of Jiaying College, 2014, (04).

[3] Lianghui Wang. Research on the terminal business integration of express delivery in university campus[J]. Knowledge Economy, 2013, (16). [4] Diyue Cong, Songjun Hu. Study on the operation mode of campus express self-mentioning shop[J]. Science and Industry, 2013, (8).

[5]Jiaqi Wang, En

Zhou , the analysis of online logistics application, based on Express tank model [J]. Logistics technology, 2015, (35).

[6]Fanqi Kong, Xiaohan Li. The campus express logistics mode [J]. China Market, 2015, (34):118-120.

[7]Lan Boxiong, Zhang Yue. A New Distribution Service Model of Termina 1 Logistics [J]. Management World, 2003(06).

[8]

Chongbin

The current Situation and The Trend of Chinese Terminal Logistics. [J]. Lo gistics technology and applications, 2016, (09). 